\title{
The Segregation in Access to Spaces for Urban Activities during COVID- 19 Pandemic in Relation to Gated Communities in Egypt
}

\author{
Hellen Aziz, Salma Ellakany \\ Technical University of Berlin, Germany \\ aziz.I@campus.tu-berlin.de | ellakany.salma@gmail.com
}

\begin{abstract}
Despite the long history of physical and social segregation by various types of gated communities in Egypt, they are attracting more residents. This is a result of the sense of privacy, security, access to proper services and the quality of green areas and public spaces that they offer. In most cases, such privileges and spaces for urban activities have restricted access to users who do not own residential units in such gated communities. With the current COVID-19 pandemic, starting in early 2020, and the Egyptian government's preventive measures, people's daily lives have been affected both economically and socially. Regulations such as the application of a curfew, and the closure of public services and facilities have had a considerable impact on population's urban activities and the use of the public spaces. Yet, it could be argued that urban activities within gated communities have increased as the residents were forced to stay at home, or within the gated compounds' walls. Thus, this paper investigates the use of the spaces for urban activities inside the gated communities; whether residential or beach destinations, in Egypt during the pandemic. It then studies the segregation in the rights of use of open urban spaces inside and outside gated communities, during the pandemic.
\end{abstract}

Keywords: public spaces, COVID-19, gated communities. physical segregation, social segregation, segregation in urban activities

To cite this article:

Aziz, H., Ellakany, S. (202I) The Segregation in Access to Spaces for Urban Activities during COVID-19 Pandemic in Relation to Gated Communities in Egypt, The Journal of Public Space, 6(I), I23-I34, DOI 10.3289|/jps.v6il.|434

This article has been double blind peer reviewed and accepted for publication in The Journal of Public Space. (c) 1 (1) This work is licensed under a Creative Commons Attribution - Non Commercial 4.0 


\section{Introduction}

In early 2020, COVID-19 pandemic started to spread from China to all over the world, with increased cases in Egypt starting February 2020 (Gomaa, 2020). Similar to impacting the economy, the virus has impacted social interactions, as well as movements. Following the World Health Organizations' recommendations of physical distancing and limited use of public spaces, Egypt started taking different measures to apply physical distancing across the country aiming to limit the number of cases during the earlier stages of the outbreak in Egypt. Such measures included strict regulations affecting the access to services, the hours of free movement and access to the beachfronts around the country. Consequently, impacting the use of the citizens to public spaces and their daily lives in general. The urban segregation in Cairo as a result of increasing the development of gated communities, has had a clear impact on the accessibility of the different social groups to urban activities. The segregation between the Upper class and low-class citizens is reflected physically through fences, gates and the limited access of 'private public space' or 'privatized' beachfronts within such gated communities. It could be argued that COVID-19 has resulted in magnified segregation as a result of the variation in the accessibility to spaces for urban activities and the variation of adherence to physical distancing measures inside gated communities compared to their surroundings.

\section{Methodology}

This paper aims to study and analyse the segregation in the residents' access to spaces for urban activities in Egypt during COVID-19 pandemic. It studies the latter's relation with the restrictions in accessibility of private public spaces in gated communities and the adherence of the private gated communities and their residents to governmental measures. First, desktop research on the concept of the Egyptian gated communities was conducted. In addition, Egyptian laws regarding the right of the public to use private 'public' spaces and privatized beachfronts inside gated communities were reviewed.

Second, direct observations on the use of green spaces and beaches in gated communities were used to understand the gated community's management and residents' responses to the government's measures, however this research has some limitation in the illustrations and photos as the paper was written post lockdown period. Furthermore, an online questionnaire was designed and shared on social media platforms, mostly targeting gated community residents, visitors and owners. With 57 responses, the questions aimed to understanding the people's behaviours during the pandemic in the residential gated communities, mainly in Cairo, as well as sea fronted gated communities along the Mediterranean Sea and the Red Sea.

\section{Gated Communities}

\section{I.I Defining gated communities}

Bödy (1997) stated the classical definition of the gated community as a group of houses with an inner network of streets, surrounded by fences with closed gates. Such fences and gates reflect the search for safety and the aim to prevent, limit or address "crime, traffic, loss of sense of community, and fear of mixing" (Shouse and Silverman, 1999). So, such fences and gates create a segregation between what is inside and what is 
outside, limiting the access of the public to the network of private properties that could include shared facilities and open spaces.

\section{I.2 Gated communities in Egypt}

In the late 20 century and the early 2 I st century, Egypt witnessed an increase of the gated communities in Cairo as a reflection of the rise of neoliberalism (Marafi, 20 I I). The former president Mubarak's government aimed to decentralize the city of Cairo, with strategies to use huge suburban communities to attract the elite from the crowded city centre to luxurious suburban communities. Policies regarding the use of desert land aimed to attract Egyptian and foreign private investors to invest in the real estate sector in Egypt (Marafi, 20II). However, the gated communities created physical and social segregation and have increased the gap between social classes (Murphy, 2010). Since 1994, the number of these gated communities has significantly increased, and the number of deluxe residential units have exceeded the market's capacities (Denis, 2006). Gated compounds in the extensions of the main urban cities such as Cairo, aim to attract permanent residents who would use their rented or owned units for the whole year. Such compounds are considered part of the New Urban Communities projects. On the other hand, gated compounds as part of touristic development projects could be considered temporary destinations and are usually sea fronted. Examples include gated compounds in Ain Sokhna by the Red Sea or the North Coast by the Mediterranean Sea, which provide private beach access for their owners. There is also a mixed type, such as the case of El Gouna by the Red Sea that combine between users who live and others who are temporary users.

\section{I.3 Public space and public private space}

Public spaces could be defined as "inclusive spaces that all people are free to use without consent or justification, thus exercising their citizenship rights" (Attia, 20 I I). Regardless of their typology, for instance whether they are green or not, they have a strong role on the wellbeing of the social and psychological wellbeing of citizens. However, similar to other developing countries, access to public spaces has been a rising concern in Egypt (Attia, 20I I). In fact, new forms of privatized public spaces have evolved with the increase in gated communities. Private public spaces could be defined as shared inclusive spaces for residents of a certain gated community being within the fences of the latter. Whereas based on the limitations of access to the gated community, the access to such private public spaces is limited or not to the general public.

\section{I.4 Gated Communities' attractiveness to residents}

The number of residents that attracted to gated communities increased due to the promise of a better quality of life. It is represented in the well maintained and managed facilities and services including infrastructure, schools, sports clubs, in addition to the access to open public spaces as well as the extensive green and pedestrian areas. According to the conducted online questionnaire, $70 \%$ of the residents of gated communities responded that they chose to live there to access quality public spaces and green areas and $60 \%$ responded that the decreased pollution in gated communities is a key factor. $54 \%$ of the respondents also chose access to proper services and $40.5 \%$ : having better status. Furthermore, $65 \%$ and $51 \%$ responded that they chose to live in 
gated communities for their sense of privacy and sense of safety, respectively. This could be analysed to be a result of having gates and fences separating the residents from 'outsiders' as well as additional security measures that vary between different gated communities from security checkpoints to using cameras and advanced data centres to monitor movement'.

\section{I.5 Legal Classification of gated communities in Egypt}

According to the law, based on the purpose of the project whether to develop new urban communities or touristic development projects, the plots are allocated to managing governmental agencies that have the right to manage, exploit or transact the allocated land following their defined purpose. First, for touristic development projects the TDA, The Tourism Development Authority, is considered the managing agency with full ownership rights in coordination with the Ministry of Defense. For new urban communities NUCA, New Urban Communities Authority, is the agency in charge. Each authority operates using a separate budget from other governmental bodies and has the right to transform such private state property to become private property through allocation or transaction to investors.

\section{I.6 The rights of access in gated communities}

Gated communities vary in how they permit different users to access their facilities. Semi-gated communities such as El Rehab and Madinaty allow non-residents as well as 'random' visitors to enter and use their facilities including commercial zones, private services and some of the spaces for urban activities such as open green areas.

Completely 'private' gated communities in Greater Cairo include Qatamiya Heights, Beverly Hills, Palm Hills and Dreamland (Denis, 2006) and sea front compounds include Marassi or Hacienda in the North Coast. The right of access of the users is segmented in those compounds based on ownership status of units as only residents with owner cards and limited pre-authorized visitors are permitted in (Ellakany, 2020). This limits the access of non-residents to spaces for urban activities, whether green spaces or beachfronts.

Legally, it is hard to identify the right of access of citizens in residential gated communities that are considered part of new urban development communities. This is due to the conditions of allocation of the land plots by NUCA to investors that move the responsibility of infrastructure provision to private investors and developers. For instance, the investors or developers of such gated communities are responsible to build the internal road networks, green spaces and pedestrian areas. The costs of the latter are covered by the higher price per meter and the service fees paid by the individual units' owners. This could be viewed as a change of public ownership of the roads to a shared ownership of the residents, managed by the gated communities' developers.

Yet, in the case of touristic developments by the beachfront, the violation to public rights is clearer. Procedures of touristic development projects follow the Prime Minister's decree no. 2908 for the year 1995, following law no. 7 for the year 1991. The TDA has the right to develop the land by itself or through investors who could buy or rent or Usufruct the land plots, with a limitation of 25 years in the case of rent or

\footnotetext{
' Nassrat, S. (2020): a resident in gated community, an interview conducted by Ellakany.
} 
Usufruct (Egyptian Gazette: Prime Minister's decree no. 2908 Sections 2-4, 1995).

Regardless of the scale of the development project, it is clear in section 8 and section 4 that the land plot sizes are defined and calculated excluding the beachfronts (Official Gazette, 1995). This means that the compounds and resorts along the sea are not permitted to hinder any citizen from using the beachfront attached, except for the facilities built by the compound or the resort (Shorouk, 2019). In fact, beachfronts are considered a public property and according to the Civil Code section 919 (Egyptian Gazette, 1948), the land of the sea is a public state property that cannot be exploited. Furthermore, section 1023 of the Civil Code (Egyptian Gazette, 1948) states that the owner of the land does not have the right to create any obstacles to hinder the benefit of its neighbouring owner. Thus citizens should have the right to access such beaches, and the right of passage through the gated communities if it this is the only path to access the beach.

\section{Access to Spaces for Urban Activities during the COVID I 9 pandemic}

According to direct observations and the conducted online survey, there was a clear segregation in both the application and the adherence to the Egyptian state's COVID-19 preventive measures. This created a variance in accessibility of spaces for urban activities between higher and lower income residents: residents who own units in gated communities and outsiders.

\section{I The Egyptian measures towards the COVID-19 pandemic}

Although the first case of COVID-19 carrier in Egypt was discovered on 14th February 2020 (Gomaa, 2020). The government started to take actions on I0th March by cancelling all the events which gather people on a large scale such as musical parties, exhibitions...etc. Moreover, it announced further measures, on the 24th of March, including a curfew from 7:00pm to 6:00am, the closure of the shops from 5:00pm and their closure during weekends, except for supermarkets and pharmacies (Prime Minister, 2020). Furthermore, the government issued the decision to close all the sports clubs and the gymnasium centres, the restaurants and the cafes with delivery permittivity.

In addition, due to the photos and videos shared on social media of the crowded beaches, on 28th of March, the local development ministry announced the closure of all the beaches in all the governorates (Cairo Scene, 2020) (El Fasla, 2020) which meant that all citizens were not allowed to sit by the beaches or swim in them. This decision included public beaches such as in Ras El Bar and Alexandria (Egypt Independent,2020) (Ahram Online, 2020) and private beaches, for example, in Ain Sokhna's gated compounds where owners escaped the city as work and schools became online (Ellakany, 2020). However, the decision of closing private and public beaches was confirmed by the announced decree on 5 th April to close all the beaches as well as public parks (Cairo Scene, 2020) (El Fasla, 2020). This aimed to limit all urban activities in both public and private urban spaces and across all governorates.

Furthermore, governmental regulations differed during national vacations. During the Easter vacation on 15th April, the government confirmed the closure of all beaches, in addition to the closure of all parks and the pedestrians' use of the Nile corniche. While during Ramadan, the curfew hours were changed to be from 9:00pm to 6:00am (Official 
Gazette, 2020). Moreover, during Eid vacation from 24 to 29th May, the governmental decision announced the closure of all the shops, beaches, public transportation means and the Nile corniche and the curfew hours were changed to start from 5:00pm (The North Africa Journal, May 2020). After El Eid, starting from June, the government announced that it is obligatory to wear masks in the public spaces, markets, banks and public transportation means, with a fine of 4000 EGP for those who do not adhere to this regulation (Farhat, 2020). Despite the increasing number of the COVID-19 cases in Egypt, the Prime Minister announced that from 26th June, most of the restrictions were lifted and the government moved to coexist with the pandemic. As restaurants, cafés, sports clubs, and cultural facilities such as cinemas and theatres were allowed to be reopened with $25 \%$ of their capacity. The decision extended the working hours of the shops and restaurants and the cafes till 9:00 and 10:00pm and public transportation means were allowed to work till midnight. Yet, the closure of the public beaches and parks were extended to avoid the expected crowds. On the other hand, private beaches were allowed to be re-opened which continues to be the case (Egyptian Streets, 2020). Hence, this reflects a segregation in the application of the governmental measures between private gated communities and their surroundings; permitting higher income citizens to enjoy open private urban spaces whether green spaces or beachfronts while prohibiting lower income residents from accessing their public counterparts.

\subsection{The Gated communities' residents use of spaces for urban activities during COVID 19 lockdown}

Unified measures to prohibit access to spaces for urban activities, were not enforced on 'private' urban spaces inside gated communities. Hence, during the curfew, it was observed that in most of the gated compounds, the residents were permitted to walk, cycle and run within the gated compounds with no curfew in place and even some shops were open after curfew hours with limited access to the residents (Ellakany, 2020). Additionally, based on the online questionnaire, the majority of the respondents, around $60.5 \%$, did not adhere to the curfew hours inside the gated community. Around $58 \%$ of the respondents mentioned that their use of spaces for urban activities increased than before COVID-19, while $21 \%$ of the respondents stated that it was the same as before the pandemic and $21 \%$ stated that their use of open spaces decreased during the COVID- 19 lockdown. In addition, walking was the main activity done in the open spaces during the pandemic according to $74 \%$ of the respondents, whereas the answers indicate that other activities included meeting their friends and family as selected by $45.5 \%$ of the respondents and cycling as selected by $26.3 \%$. While running and picnic were activities done by $22.8 \%$ and $17.5 \%$ of the respondents respectively. As El Eid, which is the Muslims' Feast, is one of the key vacations in Egypt for the citizens to celebrate in open spaces or by the sea, the variance in social interaction patterns and the adherence to governmental measures were clearly observed. Even before El Eid, roads leading to the Nile Corniche in Cairo, the 'free' pedestrian path along the Nile, were blocked in some areas, as observed in Zamalek, abiding by the measures applied in April and May. Similarly parks and all public recreational facilities were closed and the curfew starting 5:00pm was strongly adhered to. In terms of access to the beach, other than having no public beaches open and the roads closed during curfew hours, the limited public transport hindered any citizens who are not car 
owners to travel to the beachside and view it even from a distance. This formed another layer of segregation between citizens who could afford owning cars and who could not.

On the other hand, the application of curfew hours varied in the different sea fronted gated communities. On one hand, the curfew was applied and monitored by the police within gated compounds in the North Coast ${ }^{2}$, but on the other, measures were not applied in most compounds in Ain El Sokhna. Even moving between the different Ain El Sokhna compounds, along the main road, connecting Cairo and the city of Hurghada, after curfew hours was possible with no monitoring and there was lack of adherence to preventive measures within the gated communities (Ellakany, 2020). Moreover, the responses of the online questionnaire confirms that the majority, around $57.7 \%$ of the respondents, did not adhere to the curfew hours inside the gated sea fronted gated compounds, however in terms of abiding to the curfew outside the gated communities, the percentage was less as only $38.5 \%$ did not adhere to the curfew.

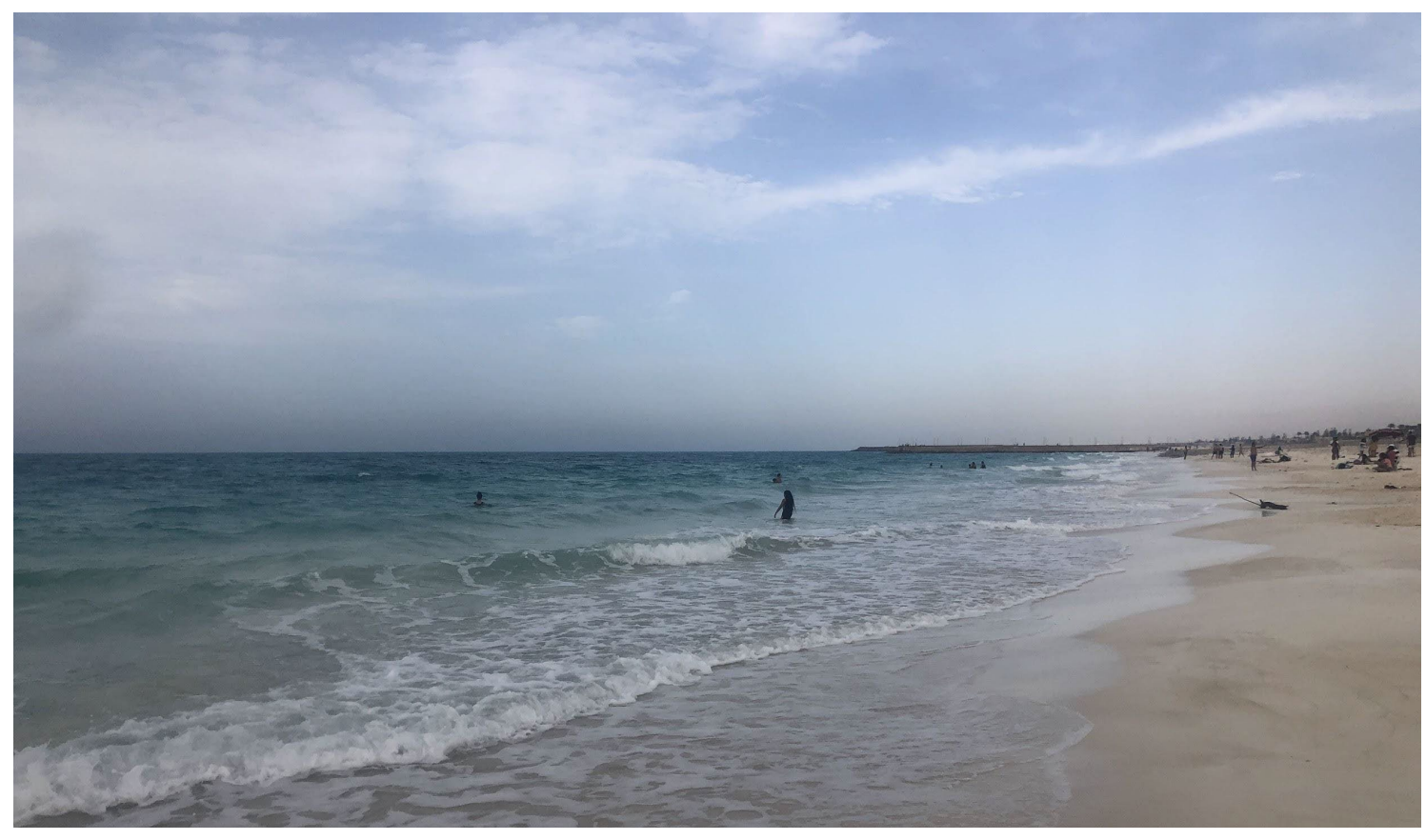

Figure I. People swimming and sitting at the beach from a distance. Taken in Marina El Alamein gated compound in the North Coast on the 12 of June, before opening private beaches (Author 2020)

In addition, based on the online questionnaire, around $44.6 \%$ of the respondents (26 of 65) went to the sea fronted gated communities such as the North Coast, Marsa Allam, El Gouna and Ain El Sokhna during the lockdown. The majority of them around $65.5 \%$ of the respondents entered the gate as owners while the others entered as visitors or renters. Their duration of stay varied from one day to a month or more but the majority, around $54 \%$, stayed there for a few days. Their reasons to stay during the lockdown were various, including staying with friends and family, enjoying the open spaces for urban activities or for health and safety reasons: avoiding crowded spaces.

${ }^{2}$ Khairy, R. (2020): a resident in gated community. An interview conducted by Ellakany 
The Segregation in Access to Spaces for Urban Activities during COVID-19 Pandemic
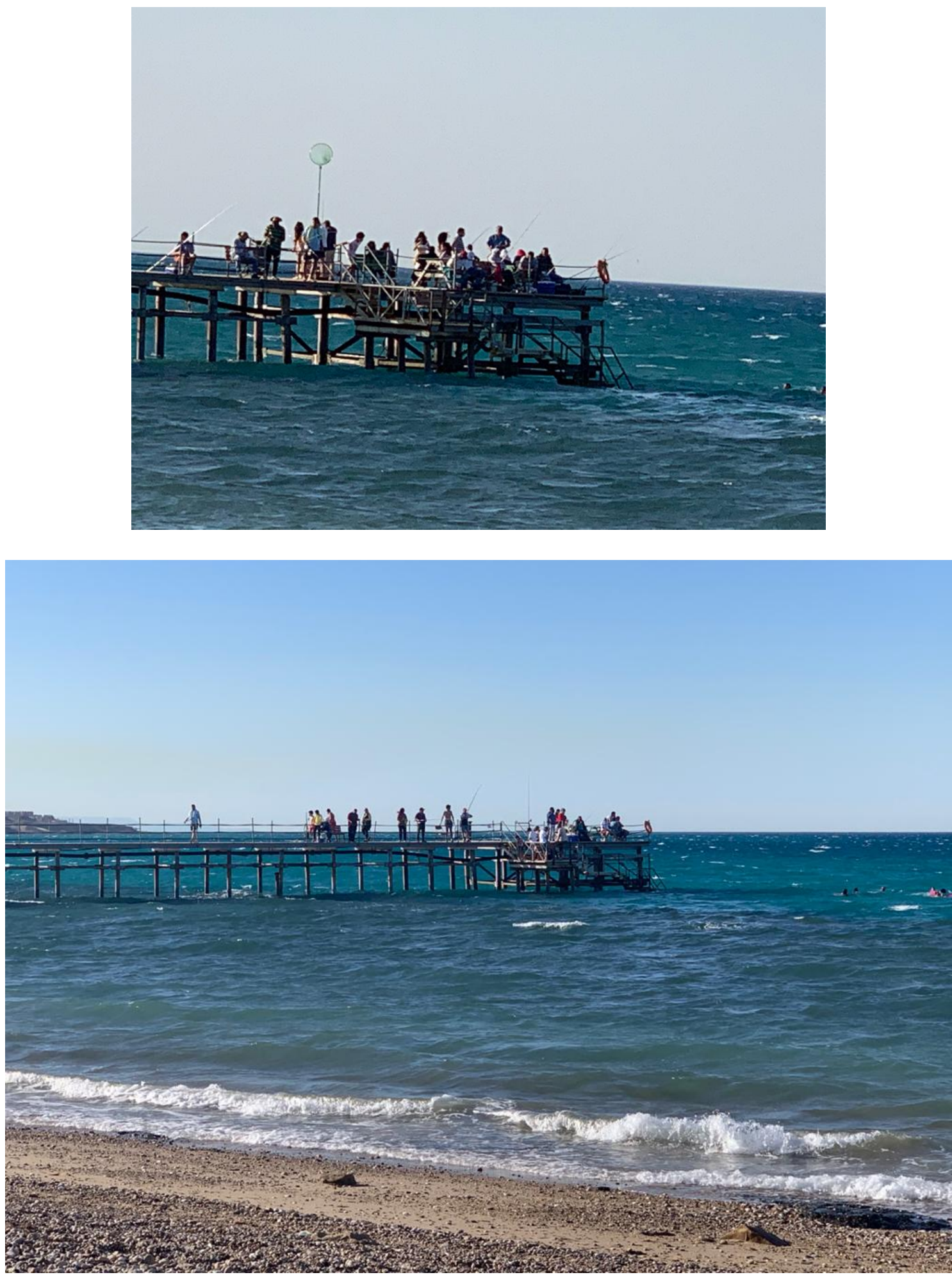

Figures 2 and 3. People fishing and sitting at the beach from a distance. Taken in Piacera gated compound in Ain El Sokhna during Eid Vacation ${ }^{3}$

\footnotetext{
${ }^{3}$ Khalil, N. (2020): a resident in gated community. An interview conducted by Ellakany
} 
However, the main reason for $84.6 \%$ of the respondents was to enjoy private beaches that were open during the lockdown. Although, announced governmental measures emphasized that all private and public beaches were to remain closed, some sea fronted gated compounds residents and their authorized visitors, friends and family of the residents, were able to access and use the beach whether by sitting, walking swimming or fishing, as shown in figure $1,2,3$.

This was even confirmed through the online questionnaire, as around $92 \%$ and $88 \%$ of the respondents respectively mentioned in the questionnaire that their main activities in sea fronted gated communities were swimming or sitting in front of the sea. In addition to other activities: walking, meeting friends, running, picnic and cycling.

\section{Conclusion}

The purpose of gated communities in Egypt is the development of new urban settlements and tourism development projects as well as attracting private investors for economic development. However, it is evident that they have caused different layers of urban segregation. This applies to all gated compounds whether they are located in extensions to major urban cities such as Cairo or along the coasts of the Mediterranean or Red Sea and whether they are used by their owners permanently or temporarily. This urban segregation is physically visible through the use of fences and gates that create a physical barrier to deliver a sense of safety and sense of security; a key promise for residential unit owners in those compounds. The sense of security in addition to accessing quality 'privatized' urban spaces could be considered main attractions for people choose living in gated communities.

The gated communities' right to build physical barriers creates layers of social segregation between 'insiders' and 'outsiders' whether in terms of access to facilities or the adherence of governing measures and laws. The gates and fences of some gated communities limit the access of the public citizens to 'privatized' facilities and services including green spaces and pedestrian areas. Yet, it is hard to distinguish whether public citizens should have the right to access the internal networks of open spaces of such gated compounds as they are privately developed with minimal to no support from the government. Similarly, sea fronted gated communities limit the access of the citizens to sea fronts. In this case, as sea land is considered public state property, hindering the access of the citizens is considered a violation of public rights.

This segregation between has magnified the social segregation during COVID-19 lockdown measures. Despite the government taking inclusive measures that cover all citizens at the start of the COVID 19 lockdown to control the outbreak, there was a variation in the adherence of the gated communities to the COVID- 19 state measures from their surroundings. Although the government's measures limited free movement through having a curfew and prohibiting access to public spaces, gated communities as private property were not subject to monitoring by the state. This resulted in lack of adherence of the government measures within gated compounds, creating a larger degree of variance of access to spaces for urban activities between gated community residents and non-residents. Non-residents had no access to any recreational or open spaces for walking, cycling, running, social interactions and swimming, while based on observation and the online questionnaire, residents and their permitted visitors have shown an increase in the use of public space for urban activities. This was due to 
residents staying at 'home' which included their residential units and the in-between spaces within the gated compound's walls. This social segregation was even magnified directly by the state through the differentiation in the measures applied to 'privatized' beaches that are currently open and public beaches that remain closed. The paradox being that the restricted access of non-owners to private beaches is considered primarily a violation of citizen rights.

This reflects how gated compounds are treated by the state as isolated zones. This is initially enforced by the allocation of land plots to governmental agencies, NUCA, TDA, with separate budgets and full authority through the right to manage, exploit or transact the allocated land. It is also enforced by the lack of clarity in the laws in terms of citizens' right to pass or not and the lack of adherence to fines related to the violation of the sea fronted gated compounds in allowing citizens' access to public state property: beach areas. Another reason is the differentiation in the application of the regulations and policies on 'private' spaces for urban activities and public spaces for urban activities. Finally, the lack of monitoring and controlling by the state to the abidance to policies and regulations inside gated compounds.

As the COVID 19 pandemic was a unique sudden case for both the gated compounds and the state, there are key learnings. First, measures that prohibit access of citizens to spaces for urban activities could be less strict in terms of complete prohibition but remain limiting in terms of number of citizens to ensure safety of citizens. Second, for existing gated communities that have had owners paying higher rates in return for quality private services, there should be clear distinction of the rights of owners versus non-owners on the level of the state where measures should be similarly applied to all citizens regardless of their income and related privileges. Third, for land plots under development as gated communities, semi-gated compounds such as the model of Al Rehab or Madinaty that balance between private properties and networks of private open spaces and services accessible to the public could offer a better option and should be enforced through the state agreements with investors and developers. Optimally, desert land developed should have new alternative models rather than the development of gated communities. Because gates and fences would always form a certain form of segregation regardless of type. Yet, further research needs to be conducted to find alternative models that would ensure the access to quality-maintained spaces for urban activities even when made more accessible to the public.

\section{References}

Attia, S. (20I I). "Rethinking Public Space in Cairo: The Appropriated Tahrir Square", published as part of Trialog 108 (Online) Available at https://www.cpasegypt.com/pdf/Sahar_Attia/Rethinking\%20Public\%20Space\%20in\%20Cairo.pdf (accessed 29 July 202I)

Bődy, P. (1998) "Lukovich Tamás: A posztmodern kor városépítészetének kihívásai", Tér és Társadalom, 12(4), PP. 16I-164. doi: 10.17649/TET.12.4.494.

Cairo Scene (2020), A media agent and online newspaper (accessed 29 July 2020).

Denis, E. (2006). "Cairo as Neoliberal Capital". In Singerman, D. and Amar, P. (eds.) Cairo Cosmopolitan: politics, culture and urban space in the new globalized Middle East (47-7I). The American University in Cairo Press. 
Egypt Independent (2020), "Damietta Governor closes beaches as part of anti-virus measures", published on 28 March 2020. (Online) Available at https://egyptindependent.com/damiettagovernor-closes-beaches-as-part-of-anti-virus-measures/ (accessed on 30 July 2020).

Egyptian Streets (2020): "Egypt Lifts Most COVID-1 9 Restrictions, Moves to 'Coexist' With the Virus", published on Egyptian Streets news on 23 June 2020. (Online) Available at https://egyptianstreets.com/2020/06/23/egypt-lifts-most-COVID-19-restrictions-moves-tocoexist-with-the-virus/,(accessed 29 July 2020).

EIFasla (2020). "The Egyptian regulations during COVID-I 9 pandemic", published on El Fasla online media agent, (accessed 29 July 2020).

Farhat, T. (2020), "Citizens not wearing face masks will face EGP4,000 penalty, imprisonment: Radwan", published on Daily News Egypt on 21 May 2020 (accessed 29 July 2020).

Gomaa, A. (2020), "The Ministry of Health reveals the fate of the first case of COVID-19 in Egypt". (Online) Available at :https://www.msn.com/ar-eg/news/national/, published on Masrawy newspaper on 15 February 2020 (accessed 29 July 2020).

Marafi, S. (20I I). "The Neoliberal Dream of Segregation: Rethinking gated communities in Greater Cairo" (Master Thesis)

Masrawy (2019). "It has been stipulated for 40 years .. Learn about the crisis of using beaches", published on Masrawy newspaper on 7 September 2019. (Online) Available at https://www.masrawy.com/news/news_egypt/details/2019/9/7/1630536/\%D9 (accessed on 29 July 2020)

Murphy, J. (2010). "The Nationalist Neoliberalism of your Desires: The case of Egypt” (Bachelor Thesis) 
The Segregation in Access to Spaces for Urban Activities during COVID-19 Pandemic

Official Gazette (1991): Law no. 7 of year 199| regarding private state property, the desert land outside the 'Zemam': city boundaries.

Official Gazette (1995). Prime Minister's decree no. 2908 of year 1995

Official Gazette (2020). Degree from the prime minister, based on the degree no. 768 and 740 of year 2020. Announced in April 2020

Osama, S. (2020). "Egypt closes some beaches as people flock to seaside amid coronavirus crisis", published on Ahram Online on 28 March 2020. (Online) Available at http://english.ahram.org.eg/NewsContent///64/366 I54/Egypt/Politics-/Egypt-closes-somebeaches-as-people-flock-to-seasi.aspx (accessed 30 July 2020).

Prime Minister (2020): Degree no. 768 of year 2020, announced on 24 March 2020

Shorouknews (2019). "The Federation of Chambers of Commerce submits a memo to the Cabinet against the fees of exploiting the beach", (Online) Available at https://www.shorouknews.com/news/view.aspx? cdate $=01092019 \&$ id $=1$ c6f3a65-bcff-4e32b525-ee8c6c2c5895\&fbclid=IwAR20J30FSNtfwLX-

Zp2Hgg6VJCleZ_S6PzgQwknlYcySfj892wQ07TLnTB8 (accessed on 29 July 2020)

Shouse, N. and Silverman, R. (1999). "Public facilities in gated communities", Urban Land, 58(6), 54.

The North Africa Journal (2020). "Egypt: Eid al-Fitr under lockdown”, published on 21 May 2020, available online at http://north-africa.com/2020/05/egypt-eid-al-fitr-under-lockdown/ (accessed on 19 July 2020) 